\title{
"A STUDY ON THE ROLE OF ADVERTISEMENTS IN INSTIGATING PESTER POWER IN CHILDREN"
}

\author{
Kamala TN.*
}

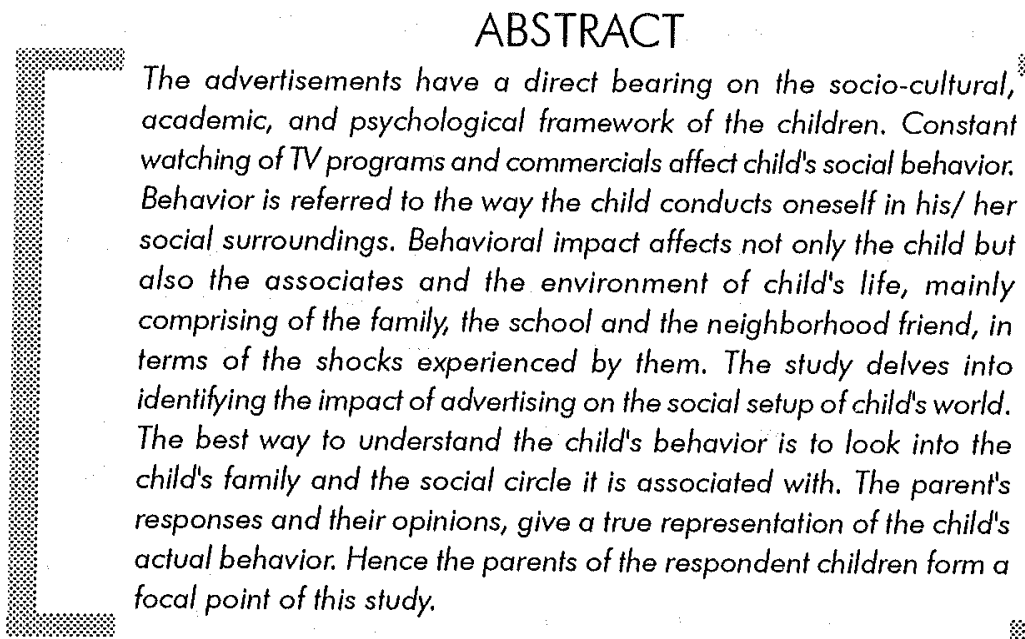

\footnotetext{
* kamalatn@gmail.com
} 


\section{Introduction}

Communication package in marketing constantly has been making its effort to take attention of the consumers. It aims at exchange of information between the buyers and sellers. Beyond informing it also tries to remind and persuade the consumers so that they respond to the product or service being offered. Marketer is not leaving a single stone unturned in his effort of reaching to new markets. He has suddenly realized the potential and emerging consumer segment 'the children and putting his best effort forward to acquire the attention of this emerging segment. Advertisements have been an effective communication tool in reaching to this younger generation in all its fineries.

Effect of advertising on the child consumer: Once we could find, children craving to play in the neighborhood with their friends on Sunday mornings and holidays. Now thanks to changing lifestyle and improved technology, we can find groups of young children clustered around the television making all the guess work on the next probable program or glued to cartoon films. TV viewership is universal and often we can find the entire family engrossed in watching number of TV programs and serials. This has been a consistent story in many of the Indian house holds.

Children learn by what they watch: Learning is a change in behavior as a result of experience. Reinforcement plays a central role in learning process. "According to law of effect, Reinforcement can be defined as anything that both increases the strength of the response and tends to induce repetitions of the behavior that preceded the reinforcement".

Hence advertisements watched repeatedly tend to leave an impression whether good or bad on children. Children especially like to watch the ads as the visual displays are more impressive due to their moving, colorful and attractive presentation. The advertising have a direct bearing on the socio-cultural, academic and psychological framework of the children. Constant watching of TV programs and commercials could surely affect the child's behavior. Behavioral impact affects the family environment as children form the focal point of any Indian family system. The changing socio economic scenario also has been playing a major role in forming 
the behavior and inculcating value system in the growing up children. Families are going through a tremendous change in their own social status, family customs, culture and lifestyles. Children are acquiring new status of importance in all the activities of the family. Children have emerged as a centric point of the family, may be due to the decreasing family size. Majority of issues which, once, were solely decided by the head of the family has now changed to 'Decision Making Units' including the child as a major participant in the decision making process. Children now not only are able to decide about what they want, they even influence buying number of products for the other members of the family.

Role of marketers: Earlier the father was the head of the family who considered to be making decisions for the entire family. Marketers seem to have realized the changes taking place in the current family system. Accordingly he is gearing to adjust to the changing scenario targeting father the decision maker as the 'Customer is the King' to the 'Prince and the Princess also who are forming the DMU' (Decision Making Unit.) They are trying to reach the consumer psyche of the children through advertisements. Hence the study delves in to identifying the impact of advertising on the social set up of the child's world. The effort has been made to understand the child's behavior with reference to watching TV ads. The true picture of the child's behavior is ascertained by the parent's opinion on various issues related to children's behavior. Thus the study focuses on identifying the parents yielding to the demands of children. Hence the topic of importance is "The Role of Advertisements in Instigating Pester Power of Children".

\section{Objectives of the Study}

1. To ascertain viewing of TV commercials by the children

2. To understand the ad recall capacity, and demanding for products by children

3. To assess the level of economic freedom enjoyed by the children

4. To analyze the role of ads in attitude and value formation of children

5. To recognize the child as an influencer in family purchases

\section{Statement of the Problem}

It is not only difficult to restrict the children from watching $T V$, but is much impossible to eliminate an exposure of children to all the marketing 
messages. Advertising and other forms of promotion directed at children has created a growing concern towards the increasing viewing options of children. There has been a general concern over the commercials which portray the children in every advertisement. The commercials directly or indirectly induce the children in to buying habits there by creating a 'Child Consumer'. Children pester the parents until they yield to the demands of their little ones. This is raises a question of whether the developing age of the young minds are becoming more and more materialistic and getting imbibed with a demanding nature. Hence, this study attempts to evaluate the effectiveness of ads during the formative age of young children. An attempt also has been made to identify the children's demanding attitude and development of pester power after they watch the TV commercials. Hence, the topic of this study is "A Study on the Role of Advertisements in Instigating Pester Power of Children" in the present context assumes a special significance.

SCOPE OF THE STUDY: The study has covered the geographical area of metropolitan city of Bangalore. The respondents are the parents of 'children respondents' of different schools in Bangalore. Respondents are the parents of children ranging between the age group of six and twelve years are covered under this study. Socio economic class (SEC), gender and occupation of the parental background have been covered under the study. The study has justified and establishes responses with reference to the parents' viewpoints to understand the impact of child's behavior on the family. The study has also tried to evaluate the impact of children's changing attitude in view of advertising.

\section{Research Methodology}

Type of Research: It is a descriptive type of a research aimed at finding the effectiveness of the advertisements on the buying behavior that is reflecting in attitude formation of children.

\section{Data Collection}

Primary Data: The study mainly delves on the primary data collected through survey method for addressing and analyzing the issues. Information has been collected form the parents of the children respondents through 
personal interview method. Structured questionnaires have been made use with quantitative and qualitative queries for the purpose. Secondary Data: Secondary data is collected from various publications, websites, ad agencies, company catalogues, brochures; journals, etc have been used extensively to strengthen the analysis.

\section{Sample}

Sampling Unit: The respondents are the parents of 'children respondents'. Socio, economic, age, gender and occupational factors have been considered while analyzing the parameters of interest. Sample parents unit is drawn from the type of the school their children studied. These are the representative sample of children aged between six and twelve studying in government and private schools.

Sample Size: Hundred parents randomly chosen from out of 368 children samples. Technique: The stratified quota sampling method has been adopted for choosing the children respondents where in, a uniform number and gender of samples has been chosen from targeted schools. Quota sampling has been adopted in choosing the parent respondents. Parent's education, occupation, income, age and religion have been considered for the study.

Statistical Tools: The constructed schedules and questionnaires were used for the survey purpose. The questionnaire comprised of open ended and closed ended questions. The structured and unstructured questionnaires are used for individual interviews and the focus group studies. The recorded observations of the personal interviews of individual and group have been used while data interpretation. Statistical Techniques: Statistical techniques like drawing percentages for generalizations, use of table for tabulating the primary, qualitative, and quantitative data and use of graphs for better pictorial representation of the analysis has been made use of. Plan of analysis: Primary information of both qualitative and quantitative nature is obtained by administering the schedules, and questionnaires. The questionnaires and schedules contain projective and direct queries. The quantitative, qualitative, and direct queries are interpreted as per the set characteristics in the concepts. The structured and unstructured interviews 
and the information collected by observation also are interpreted according to the set concepts. The discussion of the focus group also is used in the concept of interpretation. The intention behind each and every direct and indirect query has been dealt in the concept of each table.

\section{Limitations of the Study}

The study is confined to the buying response of children with regard to television advertising only. Study limits to the children in the age group of 6-12 years.

Study is confined to the metropolitan city of Bangalore. Generalizations can be at the macro level but enough care regarding the change in culture, attitude etc of the groups where results have to be administered, need to be taken care.

\section{Analysis and Interpretation}

"Once they were the children: Today they are the hidden persuaders".

As buyers children play an important part of the consumer market. They not only play the role of decision makers for their own usage products but also influence the adult purchase decisions. Marketers have become extremely interested in understanding the child consumer as they would be emerging as a highly prospective consumer segment of the 21 st century. The raising child centered societal system has given way for new avenues to be identified by the marketer.

Children are bound to imitate what looks glamorous in the commercials and it affects the eating habits, spoken language, dressing sense, the idea of joy and misrepresenting the source of happiness in life. The study identifies children as their splendid audience as they watch lots of ads and spend lots of pocket money. The study tries to analyze children's demanding nature due to the influence of ads in terms of qualitative and quantitative measures. 
Table. 1 Children's Average Time Spent on Watching TV Daily

\begin{tabular}{|l|c|}
\hline No of hrs & \% of Children \\
\hline $1 \mathrm{hr}$ & 27 \\
$2 \mathrm{hrs}$ & 34 \\
$3 \mathrm{hrs}$ & 26 \\
$>4 \mathrm{hrs}$ & 13 \\
\hline Total & 100 \\
\hline
\end{tabular}

Table. 1 clearly shows the precious time lost in the child's life merely watching Television. $27 \%$ of children loose out nearly one hour a day, there are $13 \%$ of children loosing more than 4 hrs a day. Majority of children i.e. $60 \%$ put together loosing 2 to 3 hrs a day. It shows the seriousness of constant impact it would be leaving on the minds of growing children.

Table-2 - Children's Desire to Watch The Advertisements

\begin{tabular}{|c|c|c|c|c|c|}
\hline $\begin{array}{c}\text { Preference for } \\
\text { Ads Always }\end{array}$ & $\begin{array}{c}\text { Very } \\
\text { often }\end{array}$ & $\begin{array}{c}\text { Some } \\
\text { times }\end{array}$ & $\begin{array}{c}\text { Less } \\
\text { Often }\end{array}$ & Never & Total \\
\hline 10 & 16 & 41 & 29 & 4 & 100 \\
\hline
\end{tabular}

Table no. 2 indicates the preference of children watching the TV advertisements. There are $10 \%$ of children always wanting to watch the ads. There are only $4 \%$ never prefer to watch. Considering the majority number of children preferring to watch the ads are much higher than those who less prefers to watch the ads. Children enjoy watching the ads: Majority children watch TV for more than 2-3 hirs ever yday. Children have difficulty in distinguishing advertisement from reality and may not understand that ads are there to sell something. In fact, children watching TV offen find the commercials more engaging than the programs. Watching of advertising from an early age leaves an impact, as fresh minds are imbibed 
with learning whatever comes across their way, making them the consumers of commercial messages.

Table 3. The Child's behavior after Seeing the Advertisements

\begin{tabular}{|l|c|c|c|l|}
\hline Behavior & Demanding & Crying & Pestering & Total \\
\hline$\%$ of Children & 36 & 25 & 39 & 100 \\
\hline
\end{tabular}

Source: Field Survey

The children are very emotional; Table 3 shows the emotional outburst of children as post-advertisements consequences. Children cannot suppress their feelings. They watch the advertisements and start pestering the parents to get the products. Ads disturb the mental peace of the children; the children are found getting disturbed once they see things in the ads. They become more demanding, crying and being frustrated for things and end up pestering until the parents yield to their requests. Parents struggle hard to convince the insisting young lots whom they don't want to displease.

Table: 4 Children want to buy the things Immediately after they See the Ads

\begin{tabular}{|l|c|}
\hline \multicolumn{1}{|c|}{ Effect of Ads } & \% of Children \\
\hline Immediately & 3 \\
\hline within a day or two & 16 \\
\hline within week & 46 \\
\hline sometime later & 23 \\
\hline Never & 12 \\
\hline Total & $\mathbf{1 0 0}$ \\
\hline
\end{tabular}

Source:Field Survey

Ads act as catalyst in child's buying behavior: Table 4 shows the parent's concern on the major role TV plays in purchase decision of their children. Children get to know lot of information about the products and its usages through television. Present days technological and information explosion has made the children techno centric. TV acts as a catalyst in child's buying behavior by providing huge amount of information. Though the ratio of children buying immediately is relatively low more than $50 \%$ seem 
to be demanding and pestering the parents to buy with in a week's time. It does show the tremendous impact the ads playing on the children buying behavior.

Table 5. Children Have Total Ad Recall

\begin{tabular}{|l|r|}
\hline Capacity of Ad Recall & $\%$ of Children \\
\hline All the Ads & 15 \\
Many of them & 39 \\
Few of them & 36 \\
Only one or two & 6 \\
None & 4 \\
\hline Total & 100 \\
\hline
\end{tabular}

Source: Field Survey

Children have complete ad recall: Table 5 clearly identifies the capacity of child retention. Children can recite even the jingles of all the ads they come across with. They even imitate the brand ambassadors and remain funed to experience throughout TV programs. They do not switch off as the adults do during the TV viewing. It is a very minute percentile of children who cannot recall the ads. Children are exposed to brands and ad repetition, can affect in creating the junior consumer brand loyals.

Table 6. Parents Give Pocket Money

\begin{tabular}{|c|c|}
\hline Yes & 42 \\
\hline No & 58 \\
\hline Total & 100 \\
\hline
\end{tabular}

Source: Field Survey

Pocket Money a freedom provider; Table 6 shows almost equal numbers of children are provided with pocket money. Change in lifestyle and parental concern towards keeping their children happy has provided much financial freedom for today's child consumer. Many families cultivated habit of giving pocket money has lead the children to expect and demand for it. 
Table 7. Monthly Amount Given as Pocket Money

\begin{tabular}{|l|c|}
\hline \multicolumn{1}{|c|}{ Rupees } & \% Children \\
\hline No Pocket Money & 42 \\
\hline$>$ Rs 50 & 10 \\
\hline Rs. $50-100$ & 22 \\
\hline Rs. $100-200$ & 8 \\
\hline Rs $200-300$ & 7 \\
\hline$<300$ & 11 \\
\hline Total & 100 \\
\hline
\end{tabular}

Source: Field Survey

How much pocket money: Table 7 shows the pocket allowance spent by the children per month. Children receive pocket money ranging from less than rupees fifty to more than three hundred a month. Table 7 reveals that $42 \%$ of children do not get the pocket money. Majority of children spend around 100-200 every month. Very few spend less than fifty rupees. Considerable number of children can spend more than two hundred every month.

Table 8. Children Allowed to Spend the Money

\begin{tabular}{|l|c|}
\hline Freedom Enjoyed & \% of Children \\
\hline Always & 5 \\
\hline V.Often & 8 \\
\hline Some Times & 30 \\
\hline Less Often & 28 \\
\hline Never & 29 \\
\hline Total & 100 \\
\hline \hline
\end{tabular}

Source: Field Survey 
Children demand for freedom to buy the product of their choice: Table 8 depicts the freedom allowed for children in buying the products of their choice. Today's children unlike those of yester years have tremendous knowledge about the products and product features. They know what they want and they are sure of what they need to buy. Majority of the children are allowed to buy sometime or the other. The analysis reveals that in spite of the freedom enjoyed to get the pocket money, when it comes to spending, in a majority of instances, it seem to be under the guidance of the parents.

Table 9. Parents Yielding to Children's Purchase Requests

\begin{tabular}{|l|c|}
\hline Parents Response & \% of Children \\
\hline Always & 9 \\
V.Often & 20 \\
Some Times & 54 \\
Less often & 16 \\
Never & 1 \\
\hline Total & 100 \\
\hline
\end{tabular}

Source: Field Survey

Parents yield to their children's demands; Table 9 shows the parents yielding to their children's demands, which shows the children's indirect buying power. Children pester parents after seeing the ads. They nag their parents. They show their resentments in various ways. To avoid unpleasant atmosphere of the house, parents succumb and yield to their demands. Very insignificant percent do not yield to the demands of the children. A few will always, or very often yield to children's demand. Majority of them yield to their demands at least sometimes. Only a few of them yield to their demands less often. 
Table - 10. Children's Behavior if the Parents do not Yield to the Demands

\begin{tabular}{|l|c|}
\hline Behavior & \% of Children \\
\hline Fighting & 16 \\
Frustarted & 23 \\
Upset & 54 \\
Hungerstrike & 7 \\
\hline Total & 100 \\
\hline
\end{tabular}

Source: Field Survey

Children become unmanageable; Table 10 shows the different types of deviant behavior of the children if the things are not bought after seeing the ads. Children pester their parents for the things they watch on Television. They keep on nagging until the parents yield to their requests. Till an understanding establishes between the parents and the children, parents have to go through an unmanageable young lot, whose sentiment they don't want to hurt. Majority of children become upset if they do not get what they want. Many of them become stubborn and another lot starts fighting. A few more even go on hunger strike until they get what they want.

Table 12. Children's Role in Influencing Household Goods

\begin{tabular}{|l|c|}
\hline Children Influence & \% of Children \\
\hline Full Extent & 10 \\
Large Extent & 20 \\
To Some Extent & 30 \\
Least Extent & 16 \\
Not at All & 24 \\
\hline Total & 100 \\
\hline
\end{tabular}

Source: Field Suney 
Children as initiators; Table 12 shows the influential role-played by the children in family purchases. Children enjoy an important position in every household in today's family. Parents strive hard to provide them with the things once they were deprived of. Often parents seek the opinion of their children in many of the household purchases. It is more of a gesture extended towards the children by their parents. Hence, quite often parents involve their children in purchase decision of the household articles also. It is only one fourth of the respondents households are not affected by the children's influences. Majority of the households are affected to some extent. Ten to twenty percent of the families are affected by their influences to a larger to full extent.

Table. 13 The Parents Opinion on Present Days Ads

\begin{tabular}{|l|c|c|c|c|c|c|c|}
\hline Parents Opinion & Materialistic & Moralistic & No values & Objectionable & Unethical & Unrealistic & Total \\
\hline$\%$ of Children & 32 & 14 & 20 & 7 & 6 & 21 & 100 \\
\hline
\end{tabular}

Source: Field Survey

Present day ads are more materialistic; Table 13 gives a dig into the parents' opinion on the type of communication the marketer is reaching to the children through advertisements. The marketer has found a new vivacious segment to sell his products. Marketer have realized the potential of children market. Hence, he is at his all out effort to impress the child consumer. Majority of parents feel that the marketer is communicating more of materialistic information, which has no values. Sometimes the way it is communicated is very unrealistic. Often they are unethical, and found to be objectionable.

\section{Table - 14. Present Day Ads are Misleading}

\begin{tabular}{|c|c|}
\hline Parents Opinion & $\%$ of Children \\
\hline YES & 77 \\
\hline NO & 23 \\
\hline Total & 100 \\
\hline
\end{tabular}

Source: Field Survey 
Ads are misleading the children; parents feel that ads will leave a great impact on the young minds. The naive and innocence of the child mindset gets them carried away in to the world of illusion and fantasy. Hence, table 14 looks into the opinion and shows the parents' unhappiness on misleading information in the ad claims. They feel that ads are completely misleading the young children and very few parents felt that the ads do not mislead their children.

Table 16 - Watching Ads Affect Their Children's Attitude

\begin{tabular}{|c|c|c|c|c|c|}
\hline \multirow{2}{*}{$\begin{array}{c}\text { Parents } \\
\text { Opinion }\end{array}$} & $\begin{array}{c}\text { Strongly } \\
\text { Agree }\end{array}$ & $\begin{array}{c}\text { Agree } \\
\text { Some What }\end{array}$ & $\begin{array}{c}\text { Not } \\
\text { Agree }\end{array}$ & $\begin{array}{c}\text { Strongly } \\
\text { disagree }\end{array}$ & Total \\
\cline { 2 - 6 } & 6 & 20 & 46 & 28 & 100 \\
\hline
\end{tabular}

Source: Field Survey

TV ads have an impact on the attitude of the children: Table 16 represents the impact of ads on the attitudes of children. Children become more knowledgeable as they are exposed to various new information situations. The new information brings in new faith and belief in the understanding of the children. The different kinds of information about different brands and products will enhance the level of understanding of the children. It affects their outlook and understanding of the products and their usage habits. Very few parents strongly disagreed with ads affecting the children's attitude. Majority of parents somewhat agreed to ads affecting their children's attitude. Considerable number of parents expressed a mixed opinion on agreeing for ads affecting the attitude of children.

Table 17 - Watching Ads Affect Their Children's Value System Negatively

\begin{tabular}{|c|c|c|c|c|c|c|}
\hline $\begin{array}{l}\text { Parents } \\
\text { Opinion }\end{array}$ & Full extent & Large extent & To some extent & Least extent & Not at all & Total \\
\hline & 5 & 10 & 53 & 15 & 17 & 100 \\
\hline
\end{tabular}

Source: Field Survey 
TV commercials have a negative impact on the children: Table 17 explains the effect of ads on the value systems of young children. The commercials open a way to the new world of fantasy. The impressionable mind captures all that is told in the ad, and believes it to be true. The ads affect the set of opinion, faith, belief and attitude of the children. Majority of parents said that the ads affect the children's value systems to some extent. Those who did not associate the ads with negative value system were considerably more than those who attached ads with negative values.

Table 18 - The Ethical Standard of Present Day's Ads

\begin{tabular}{|l|c|c|c|c|c|c|}
\hline $\begin{array}{l}\text { Parents } \\
\text { Opinion }\end{array}$ & $\begin{array}{c}\text { Highly } \\
\text { appreciable }\end{array}$ & $\begin{array}{c}\text { Much } \\
\text { appreciable }\end{array}$ & $\begin{array}{c}\text { Just } \\
\text { appreciable }\end{array}$ & $\begin{array}{c}\text { Not } \\
\text { appreciable }\end{array}$ & $\begin{array}{c}\text { Highly } \\
\text { unappreciable }\end{array}$ & Total \\
\hline Total & 7 & 22 & 46 & 20 & 5 & 100 \\
\hline
\end{tabular}

Source: Field Survey

Ethics in Advertisements: Table no 18 reveals the parents concern about the ads made these are not always appreciable. The marketer has started to commercialize the children community. Not that he simply would place the children's product in front of them as they are, but having realized the potentiality of "pesters' power" he would rather try to sell everything under the world. While making an effort to achieve his objective he is treating children as another consumer segment ignoring the innocence of a young mind and heart. The techniques followed by the marketer are more similar to that followed for an adult consumer. We are turning the child into a child consumer much earlier in life. Table 18 shows the ethical level, to which children are exposed to throughout their TV watching time. Majority of parents somewhat feel that the ads bring in the ethical issues subtly. The equal number of respondents seems to be disagreeing on whether the ads are ethical or not.

\section{Findings}

1. Children are loosing a precious time in their life. Average time spent in watching the TV is $2-3$ hrs a day. Even if two hrs are spent in watching the TV the child will be loosing 38 precious days in a year. 
2. Majority children found consuming TV commercials. Since the children's age is very gullible and fresh, it leaves a lasting impression in the formative period of the children.

3. Children have total ad recall unlike their adult partners. The great retention power of the children is subjected to create the brand awareness in them in turn converting children introduced to brand culture.

4. It is found that almost $50 \%$ of the children receive pocket money to the tune of more than 100 rupees a day. Majority of them are given freedom to have their choice products. Still equal number of children found taking parents help in shopping items.

5. It is found that majority times parents are yielding to their children's demands. There are very negligible cases where parents do not yield to children's requests.

6. Children found to be becoming highly aggressive and unmanageable if parents do not yield to their requests. It clearly indicates an unhealthy formation of attitudinal development.

7. Children found not only deciding their own product but influencing the buying of the other household products also.

8. Parents have felt that present day ads are more materialistic, unrealistic and with less moral values in them.

9. Parents felt that the present day ads are unnecessarily misleading the children. They were also of the opinion that ads are somewhat responsible for developing negative values and attitude in them.

10. Standards in term of ethics though not criticized were not well appreciated too.

11. The personal interview with the respondents has revealed the certain positive response towards the ads. Ads have been serving good purposes like educating the children and developing self confidence and playing role of window to the world.

\section{Recommandation}

1. TV has occupied a centre place in any Indian household. Children's loosing out time in watching TV programs needs to be moderated by the parents. 
2. The impression of ads on the primitive age of children needs to be looked into more seriously by the parents and children need constant guidance in distinguishing commercials and TV programs.

3. Brand consciousness in children could be made use of more for a knowledge purpose than receiving it as commercial recipients.

4. Parents need to spend more quality time with children and it is the need of the hour to educate children on more realistic grounds.

5. TV is going to stay. Hence it is the responsibility of the family to imbibe right values and give a constant support in allowing the child to socialize to share the knowledge with others.

\section{Bibliography}

1. William D. Wells. David Prensky. John Wiley \& Sons .inc Singapore. 1996

2. Rajni Chadha, Emerging Consumer. A changing Profile of the urban Indian Housewife and its Implications. Wiley Eastern Lyd. New Age international Ltd New delhi 1995

3. Scot ward Wackman, D.B. Ronald, and Lesser Gerald, Effects of Television Advertising Consumer Socialization, Working paper, Mar keting Science Institute, (Cambridge: Mass, 1974).

4. Elizabeth B. Hurlock. Child Development sixth edition. McGraw Hill Book Company International Student Edition. 1978

5. Willium I. Wilkie Consumer Behavior, Third Edition John Wiley \& Sons., Inc New York.1994

6. S.A. Chunawalla. Advertising, Sales and Promotion Management. Himalaya Publishing House Mambai. 2002

7. Leon g. Shiffman Leslie Lazer Kanuk Consumer Behavior. First Edition. Pearson Education. New Delhi. 2004

8. M.P. Winick and C. Winic, The Television Experience: What Children see (Sage Publications: Beverly Hills, 1979)

9. "Targeting the Tots" India Today, September 30,1988, pg45. 
10. M.Vijayanunni, Census atlas, India(New Delhi: Registrar General and Census Commissioner, 1991), p. 11

11. John R.Rossiter, "Does TV Advertising Affect Children? "Journal of Advertising Research, Vol 19 (1979), pp. 49-53.

\section{Websites}

- hHtp://www.agencyfaqs.com/

- women.Timesonline.co .uk /article/0,,17909-1371512,00.html

- www.raisingkids.co.uk/fea/fea_43.asp - $27 \mathrm{k}$

- www.cartoon network.com

- www.turner.com 